\title{
Central Asia on the way of One Belt, One Road - implications for the European Union ${ }^{1}$
}

\section{One Belt, One Road - strategy or initiative?}

China's Belt and Road Initiative (BRI) was announced by Chinese President Xi Jinping during an address at the Nazarbayev University in Astana, on September 7, 2013. Xi emphasized China's desire to "jointly build an 'economic belt' along the Silk Road" with Central Asian partners to "deepen cooperation and expand development in the Euro-Asia region” (Clarke, 2017, pp. 71-79).

The phrase One Belt, One Road (OBOR) (yi dai yi lu in Chinese) refers to the "economic belt" and the "Maritime Silk Road." The maritime component of this new Silk Road concept is expected to stretch across Southeast Asia, the Indian Ocean, Persian Gulf and the Mediterranean Sea. The narratives in the expanding literature on OBOR examine Chinese motives, strategic implications, economic integration, and geopolitical importance (Lim, Chan, Tseng, Lim, 2016).

The OBOR initiative roughly follows the route of the historical Silk Road. The latter was comprised of several roads by which caravans used to transport a vast array of commodities. The journey would usually last several years and was a dangerous enterprise. Not only silk but also spices, silver, and other goods were transported via the route. Trade reached its height during China's Tang dynasty (618-906). The ancient road originated from Chang'an (now Xian) in the East and, through a series of major trade routes across Central Asia, helped to develop commerce and create cultural ties between China, India, Persia, Arabia, Greece, and Rome, and finally, even the Mediterranean. The phrase "Silk Road" was introduced in the mid-1800s by a German explorer, Ferdinand von Richthofen, who organized expeditions to China between 1868 and 1872 (Hansen, 2012).

The OBOR initiative is not simply the sum of individual projects centered around the idea of connecting China to the rest of the world via new and existent continental and maritime infrastructure. It summarizes all previous Chinese initiatives. The New Silk Road, if realized, will cover around 60 countries and thus $60 \%$ of the world's population (Szczudlik-Tatar, 2015). The states it would include are, of course, very diverse both in economic and political terms. Moreover, the new Silk Road covers both developed and developing countries, often struggling with many economic prob-

${ }^{1}$ The paper has been written under a project financed by the National Science Centre: The European Union's attitude towards Central Asia - regional and international determinants; 2014/15/B/ HS5/01591. The paper was published as: Belt and Road through Central Asia - recommendations for European Union, in: European Union and Central Asia: Policies and Reality, eds. T. Wallas, R. Fiedler, P. Osiewicz, Logos Verlag, Berlin 2018. 
lems and burdened with corruption and inefficient management systems. Furthermore, many of them are characterized by an authoritarian system. The common denominator for these countries, otherwise extremely different from one another, is that they will, most probably, be increasingly focused on multifaceted trade cooperation with China. In particular, countries with poor infrastructure see this initiative as an opportunity for modernization.

Table 1

Countries along the route of $O B O R$

\begin{tabular}{||l|l||}
\hline \multicolumn{1}{|c||}{ Regions } & \multicolumn{1}{c||}{ Countries } \\
\hline Northeast Asia (2) & China, Mongolia \\
\hline Southeast Asia (10) & $\begin{array}{l}\text { Brunei, Cambodia, Indonesia, Laos, Malaysia, Myanmar, the Philippines, Singa- } \\
\text { pore, Thailand, Vietnam }\end{array}$ \\
\hline South Asia (7) & Bangladesh, India, Nepal, Pakistan, Bhutan, the Maldives, Sri Lanka \\
\hline Central Asia (9) & $\begin{array}{l}\text { Afghanistan, Armenia, Azerbaijan, Georgia, Kazakhstan, Kyrgyzstan, Tajikistan, } \\
\text { Turkmenistan, Uzbekistan }\end{array}$ \\
\hline Middle East (15) & $\begin{array}{l}\text { Bahrain, Egypt, Iran, Iraq, Israel, Jordan, Kuwait, Lebanon, Oman, Palestine, Qa- } \\
\text { tar, Saudi Arabia, Syria, the United Arab Emirates, Yemen }\end{array}$ \\
\hline Central and Eastern & $\begin{array}{l}\text { Albania, Belarus, Bosnia and Herzegovina, Bulgarian, Croatia, Cyprus, the Czech } \\
\text { Republic, Estonia, Greece }\end{array}$ \\
\hline Europe (23) & $\begin{array}{l}\text { Hungary, Latvia, Lithuania, Macedonia, Moldova, Montenegro, Poland, Romania, } \\
\text { Russia, Serbia, Slovakia, Slovenia, Turkey, Ukraine }\end{array}$ \\
\hline
\end{tabular}

Source: Own elaboration.

There is a discussion among researchers about how OBOR's goals should be defined. Peter Cai highlights that China is using OBOR to assert its regional and global leadership. Its aim is to create a regional chain of production, where China will be the center of advanced manufacturing, innovation, and the standard setter. OBOR is also a response to decreasing growth in GDP, the uneven development of China's western provinces and the problem of excess capacity (Cai, 2017).

As an enormous project, OBOR should be analyzed from a wide perspective. According to Nicola Cesarini, OBOR is a Chinese strategy for consuming overproduction, overcapacity, excessive production, internationalization of the Chinese currency, as well as reducing unskilled unemployment in China, boosting infrastructure development in Asia, improving the regional transport capacity and gaining access to natural resources, such as oil and gas. OBOR is an emanation of Chinese soft power; it also signifies an attempt to integrate Eurasia under Chinese leadership (Cesarini, 2016, pp. 95-108).

Officially, OBOR is presented as an initiative, but one can also find statements from representatives of the Chinese authorities indicating that it is primarily a strategy permanently inscribed in Beijing's foreign policy. The Chinese Ministry of Foreign Affairs (MFA) identifies at least three major geoeconomic and geopolitical purposes of OBOR. First, internally, it will accelerate the development and growth of the western Chinese interior region and turn it into the "frontier in opening up to the world." Second, by enhancing the connections and productivity of developing Asian countries, it will elevate the status of Asia in the world industrial chain. Third, it intends to foster effective regional cooperation (Xin, 2016, pp. 113-116). 
According to Ye Zicheng, "there is a close connection between the rejuvenation of the Chinese nation and China's becoming a world power. If China does not become a world power, the rejuvenation of the Chinese nation will be incomplete. Only when it becomes a world power can we say that the total rejuvenation of the Chinese nation has been achieved" (Zicheng, 2010, p. 74).

Summing up the considerations on whether OBOR should be regarded as an initiative or a strategy, the latter is definitely the case. It is a coherent development strategy for China on its way to building a Sinocentric global system. As a grand strategy, OBOR is an instrument for achieving the following goals: promoting development and integration in Eurasia and contributing to mitigating security threats; serving Chinese national interests in economic, diplomatic, financial, and geopolitical terms; serving as an impetus, driving China to become more proactive in shaping global governance, and regional and local state security affairs, as China's interests expand in line with its overseas economic activity.

\section{OBOR's routes and its financial instruments}

There are at least six planned economic corridors: the China-Mongolia-Russia Economic Corridor (CMREC), the New Eurasian Land Bridge (NELB), the ChinaCentral Asia-Western Asia Economic Corridor (CCWAEC), the China-Indo-China Peninsula Economic Corridor (CICPEC), the China-Pakistan Economic Corridor (CPEC), and the Bangladesh-China-India-Myanmar Economic Corridor (BCIMEC) and the maritime route.

Table 2

\section{Land connections and Maritime routes}

\begin{tabular}{|l|l|}
\hline $\begin{array}{l}\text { China-Mongolia-Russia } \\
\text { (CMREC) }\end{array}$ & $\begin{array}{l}\text { Includes two economic corridors. One economic corridor starts in North- } \\
\text { ern China, goes through Hohhot, Inner Mongolia, and reaches Mongolia } \\
\text { and Russia. Another corridor starts in Northeast China, extends through } \\
\text { Manzhouli, and reaches Chita, Russia. Both rely on the Trans-Siberian } \\
\text { Railway to connect China with Europe. }\end{array}$ \\
\hline $\begin{array}{l}\text { New Eurasia Land Bridge } \\
\text { (Second Eurasia Land } \\
\text { Bridge) Economic } \\
\text { Corridor (NELB) }\end{array}$ & $\begin{array}{l}\text { A route divided into three parts that connect Lianyungang, Jiangsu Prov- } \\
\text { ince with the Port of Rotterdam in the Netherlands. Said to also possibly } \\
\text { connect to Japan, South Korea, and Europe through Lianyungang. Can } \\
\text { also reach from Iran and Russia to Hungary by way of Kazakhstan. Covers } \\
\text { over 30 nations. }\end{array}$ \\
\hline $\begin{array}{l}\text { China-Central Asia-West } \\
\text { Asia Economic Corridor } \\
\text { (CCWAEC) }\end{array}$ & $\begin{array}{l}\text { Starts in the Xinjiang Uyghur Autonomous Region, extends through the } \\
\text { Persian Gulf, and reaches the coast of the Mediterranean Sea and the Ara- } \\
\text { bian Peninsula. Connects Central Asian nations such as Kazakhstan, Kyr- } \\
\text { gyzstan, and Tajikistan as well as Iran and Turkey, includes regions that } \\
\text { are rich in oil and various mineral resources and would serve as a resource/ } \\
\text { energy source for China. }\end{array}$ \\
\hline $\begin{array}{l}\text { China-Indochina Penin- } \\
\text { sula Economic Corridor } \\
\text { (CICPEC) }\end{array}$ & $\begin{array}{l}\text { Starts in Nanning, Guangxi Zhuang Autonomous Region and Kunming, } \\
\text { Yunnan Province and ends in Singapore. China has established an FTA } \\
\text { with ASEAN and cooperated in developing the Greater Mekong Subre- } \\
\text { gion, but there are also tensions in the South China Sea, and establishment } \\
\text { of this economic corridor faces great difficulties. }\end{array}$ \\
\hline
\end{tabular}




\begin{tabular}{|l|l|}
\hline $\begin{array}{l}\text { China-Pakistan Economic } \\
\text { Corridor } \\
\text { (CPEC) }\end{array}$ & $\begin{array}{l}\text { A 3,000 km route connecting Kashgar, Xinjiang Uyghur Autonomous Re- } \\
\text { gion with Gwadar Port in Pakistan. Has the role of connecting the "One } \\
\text { Belt" with the "One Road" - an agreement between China and Pakistan to } \\
\text { cooperate broadly in areas such as energy, infrastructure, and industry in } \\
\text { addition to developing Gwadar Port. }\end{array}$ \\
\hline $\begin{array}{l}\text { The Bangladesh, China, } \\
\text { India and Myanmar Eco- } \\
\text { nomic Corridor (BCIM) }\end{array}$ & $\begin{array}{l}\text { To be established together with Bangladesh, India, and Myanmar. Through } \\
\text { this economic corridor, China can promote ties with Bangladesh and India, } \\
\text { with which it historically did not have close ties. }\end{array}$ \\
\hline $\begin{array}{l}\text { 21st-Century Maritime } \\
\text { Silk Road }\end{array}$ & $\begin{array}{l}\text { Consists of routes from the South China Sea and the Indian Ocean to Eu- } \\
\text { rope, and routes from the South China Sea to the South Pacific. In order to } \\
\text { establish the Maritime Silk Road, China would concentrate its investment } \\
\text { in 15 harbor cities including Shanghai, Tianjin, Ningbo, and Zhoushan. }\end{array}$ \\
\hline
\end{tabular}

Source: Ayoma, 2016, p. 5.

So far, Beijing has failed to convince India about OBOR. At the moment, the biggest number of investments are dedicated to the development of the economic corridor with Pakistan. In order to build the China-Pakistan Economic Corridor, China is committed to investing up to USD 45.6 billion to help Pakistan's economic development, including a USD 33.8 billion investment in the energy sector and USD 11.8 billion investment in infrastructure (the Gwadar port project accounts for USD 622 million). The two sides decided to begin collaboration in energy, infrastructure construction and other key areas of cooperation at Gwadar, and, in the future, to gradually extend it to the fields of agriculture, science and technology, finance, education, culture, and media communication (Qian, 2016, pp. 26-55).

According to estimates by China, a total of USD 8 to 10 trillion in investments will be required for OBOR. Provinces and autonomous regions have invested a total of up to 1.04 trillion renminbi (RMB) in infrastructure planned for One Belt, One Road, of which 500 billion RMB, 123.5 billion RMB, 116.7 billion RMB, and 170 billion RMB respectively will go to roads, high-speed rail, airports, and harbors. It is estimated that all costs related to investments under the OBOR project will amount to, at least, USD 10 trillion, and the RMB will inevitably function as a major currency in the investment in this regard. OBOR will also help to boost China's foreign trade, thus further promoting the global use of the RMB (Ploberger, 2017, pp. 289-305).

OBOR has huge investment project needs, not to mention the necessity of institutional and financial assurance. Specifically for this purpose, in 2015, the Asian Infrastructure Investment Bank (AIIB), an international financial institution led by China, has been established. The AIIB has USD 100 billion in capital, obtained from 57 of its founding members, with over $31 \%$ coming from China. As the largest stakeholder, China holds $26.6 \%$ of the voting power. The AIIB is a milestone in China's bid to play a more active role in global governance.

In May 2015, the China Development Bank, one of the country's policy banks, announced that as part of its efforts to boost the OBOR initiative, it would invest more than USD 890 billion dollars in over 900 projects, involving 60 countries to connect Asia and Europe. Finally, a USD 40 billion Silk Road Fund (SRF) has been created - which is an infrastructure financing vehicle that will supply funding to finance the construction of MSRI and other infrastructure (Tiezzi, 2017). 


\section{OBOR railway connections between Asia and Europe}

The idea of a land bridge between China and Europe has been a part of the vision, but there is little precision about the route and directions. The long-standing link is the Trans-Siberian railway from Vladivostok, through Moscow, to Europe, with spurs connecting Mongolia and China to the mainline. Another line from Tashkent or Almaty to Russia is a legacy of the Soviet rail network. In 1990, a line from Urumqi to Kazakhstan provided the first direct link between China and Central Asia, and in 1997 a rail link between Turkmenistan and Iran was completed, although it carried little traffic. The Kazakhstan-China rail line carried coal, minerals, and iron.

From 2011, many new railway lines which directly connect China to Europe have started to operate. The first one, Yuxinou, started operating in 2011 (Contessi, 2018, pp. 759-790). The railway lines connect many Asian and European countries with China. Poland, the Czech Republic, Germany, Spain, Russia and Uzbekistan serve as its final destinations.

The number of connections has doubled between China and Europe since the beginning of the present decade. Since 2011, when the first regular connections were started, a total of 6,637 freight warehouses have been launched in both directions, of which 3,673 in record 2017. The value of goods transported in 2016 can be estimated at over USD 22.9 billion, which accounted for approx. 4\% of total China-EU trade. By 2020, the value of transported goods may increase to USD 76.5 billion. Over 2/3 of railway depots starting from China are moving towards Europe, which reflects the overall trade surplus of China with the EU (Popławski, Kaczmarski, 2018).

Table 3

Railway connections between China and Europe

\begin{tabular}{||l|l|c|c|c|c||}
\hline \multicolumn{1}{|c|}{ City } & \multicolumn{1}{c|}{ Route } & $\begin{array}{c}\text { Distance } \\
(\mathbf{k m})\end{array}$ & $\begin{array}{c}\text { Duration } \\
(\text { days })\end{array}$ & Start & Frequency \\
\hline Yuxinou & Chongqing-Duisburg & 11,179 & 16 & July 2011 & $3 \times /$ week \\
\hline Hanxinou & Wuhan-Melnik (CZ)/Pardubice & 10,863 & 16 & Oct. 2012 & $2-3 \times /$ week \\
\hline & (CZ)Turkmenistan & & & & \\
\hline Sumanou & Suzhou-Warsaw & 11,200 & 18 & Nov. 2012 & $6-8 \times /$ week \\
\hline Rongou & Chengdu-Lodz & 9,826 & 10.5 & April 2013 & $1 \times /$ week \\
\hline Zhengou & Zhengzhou-Hamburg & 10,214 & $19-20$ & July 2013 & $1 \times /$ week \\
\hline Yixinou & Yiwu-Madrid & 13,052 & 21 & Nov. 2014 & $3 \times$ until now \\
\hline Hexinou & Hefei-Germany & 11,000 & 15 & June 2014 & $2 \times /$ month \\
\hline Xiangou & Changsha-Duisburg/Moscow & 11,808 & 18 & Oct. 2014 & Every 10 days \\
\hline & Tashkent & & & & \\
\hline Haou & Harbin-Hamburg & 9,820 & 15 & June 2015 & $1 \times /$ week \\
\hline \hline
\end{tabular}

Source: Contessi, 2018, p. 771.

The greatest advantage of rail transport is that it is an intermediate form, between slow and cheap sea transport and fast and expensive air freight. The time of transporting goods by air between China and Europe, counting from terminal to terminal is 5-9 days; via railway, 15-19 days; and by sea, 37-50 days. The competitiveness of train transport in relation to maritime transport increases for locations away from 
seaports. In many industries the pace of changes in the market is so fast that companies can be prepared to pay a rate slightly higher than for sea freight to gain time. At present, the largest number of containers is transported by the corridor running through Kazakhstan, starting from the Sino-Kazakh border crossing Alaszankou/Dostyk. In 2017, Khorgos handled the equivalent of more than 100,000 standard containers full of goods, double what was transported the year before. It aims to handle 500,000 containers by 2020 , but even that target is only around $1 \%$ of the volume of goods that travel from Asia westward by sea (Contessi, 2018, p. 774).

\section{Central Asia connections and security}

The Central Asian republics of Kazakhstan, Kyrgyzstan, Tajikistan, Turkmenistan and Uzbekistan cover an area of approximately 4 million square kilometers. Kazakhstan alone is roughly four-fifths the size of India, with a total area of 2,717,300 square kilometers. The region has been land-locked for centuries. The natural barriers that enclose this vast territory include great mountain ranges such as the Tien Shan, or Heavenly Mountains in the east, the Pamirs in the south-east and the Altai range in the north-east. In the west, the Caspian Sea provides a border between Central Asia and the Caucasus. The expansive steppe in the north, with its extreme continental temperatures, combined with the Kara Kum and Kyzl Kum deserts in the central and southern regions, have consistently been natural obstacles to the development of trade routes throughout history. For this reason, Central Asia has been considered a region with limited access to other markets. Land-locked countries such as the ones found in Central Asia usually have as much as $60 \%$ less trade than coastal states, and pay twice their transport costs. It is therefore not a coincidence that more than $80 \%$ of global trade travels by sea. What is more, one should not forget about the legacy of Soviet Russia. In the USSR, as much as in the Russian Empire that preceded it, infrastructures were built mostly around Russia's central region in a centripetal fashion. In Central Asia, transport networks mainly had a north-south orientation intended to bring raw materials - ranging from metals and hydrocarbons to cotton - to the Soviet Union. Based on Nicola P. Contessi's analysis, nowadays, out of 16 connection points with neighboring railway networks, 11 belong to Russia, two to China and the remaining ones to Kyrgyzstan, Uzbekistan and Turkmenistan. Another limitation of the Soviet legacy is the $1,520 \mathrm{~mm}$ Soviet gauge (as opposed to the $1,435 \mathrm{~mm}$ standard gauge), which constrains the interoperability of the Kazakhstani and other Central Asia states' networks with countries beyond the post-Soviet space (Contessi, 2018, pp. 759-790). In the first decade of the 21st century, China achieved the position of one of the three most important trading partners, along with EU and Russia (Laruelle, Peyrouse, 2015, pp. 190-207).

For landlocked Central Asia, the Chinese economic engine brings the prospect of new trans-Eurasian corridors, and thus it is seen as a unique historical opportunity. Between 80 and $90 \%$ of Chinese exports to Central Asia consist of finished goods such as consumer products, machinery, processed food, textiles, shoes, electronic goods, pharmaceutical products, and automobile parts. On the other side, about three quarters of Central Asian export to China consists of raw materials, crude oil, natural gas, and 
ferrous and nonferrous metals. In the first decade of the 21st century, China achieved the position of one of the three most important trading partners (China, along with the EU and Russia) for each Central Asian state. At least two Central Asian states, Kyrgyzstan and Turkmenistan, are economically dependent on China. The first, as the main location of the re-export of Chinese products, the latter acutely dependent on gas supplies from China. Tajikistan, in turn, has become the preferred gateway to enter to the Afghan market. From the opening of the border in 2004 in Kulma-Kalasu in Tajikistan, it is increasingly important for the re-export of Chinese products. Chinese bazaars in Tajikistan not only respond to the needs of the local market, but they also supply the market in Afghanistan and Uzbekistan (Peyrouse, 2008).

Central Asian states provide new markets for Chinese products; markets that could open up also to the whole of Russia, Iran, and Turkey. Thus, Central Asia is treated with great importance by China as it offers new routes bypassing the section running through Russia. In addition to providing alternative routes, OBOR aims to stabilize the situation in Xinjiang province. Beijing counts on the fact that investing and raising the living standards of the inhabitants of this province will reduce the separatist tendencies of the Uighur ethnic group. The Uighur Diaspora probably totals 11 million people, approximately 10 million of whom live in China, the vast majority of them inhabiting Xinjiang. Between 300,000 and 1 million more live in five other Central Asian states (Bovingdon, 2010, p. 11). In order to prevent separatism and radical movements, China has established a platform for effective collaboration with its neighbors. China has succeeded in developing institutional cooperation, from security to economic issues, within the framework of the Shanghai Cooperation Organization. Formally established on June 15, 2001, the SCO evolved out of annual summits among five states, that started in 1996 - Russia, China, Kazakhstan, Kyrgyzstan, and Tajikistan. In its early years, the organization focused on improving the security situation in Xinjiang and China's Central Asian neighborhood. The SCO's precursor, the Shanghai Five (formed in 1996), focused initially on confidence-building measures, which has further morphed into enhancing border security and internal security, as well as multilateral military and counterterrorism cooperation (Osiewicz, 2016, pp. 159-179).

\section{OBOR: opportunities and challenges for Central Asia}

The presence of OBOR in Central Asia will create a framework for the revival of China's abandoned initiatives and continuation of its current projects in the region. It also opens up new possibilities for boosting cooperation in the energy field. Through the implementation of infrastructure projects, mainly in the context of creating new transport, energy and telecommunications connections, China is gradually changing its existing configuration of dependencies and connections in the entire Central Asian region that had been established in Soviet times. For Chinese energy companies, the OBOR initiative is an excellent basis for expanding their business opportunities. Particular attention is paid to the extremely promising sectors of the clean and renewable energy sources, where China, based on its experience and knowledge, can offer high quality products at relatively low prices. 
The final list of infrastructural projects intended for Central Asia under the banner of the OBOR project is unclear; previous investment had stressed the creation of pipelines, refineries, highways, and power plants. For example, Kazakhstan and Kyrgyzstan have different needs; the former wants infrastructure that compliments export and energy integration with minimal disturbance to society. The latter needs roads and railroads, better energy supply, and employment opportunities. Chinese investments, on the one hand, are an opportunity to modernize infrastructure and build new installations, such as gas and oil pipelines, power plants, though, on the other hand, they raise concerns and protests concerned with the possibility that Chinese activities may be a threat to the local market. In 2016, protests forced autocratic Kazakhstan to withdraw a law allowing foreigners to lease the country's land, in what was perceived as a USD 1.9 billion imperial Chinese attempt to grab agricultural terrain, and an implied stranglehold on food production (Strenberg, Ahearn, McConnell, 2017, p. 55).

Table 4

Chinese investments in Central Asia

\begin{tabular}{||l|l|c|c||}
\hline \hline \multicolumn{1}{|c|}{ Country } & \multicolumn{1}{|c|}{ Project } & Cost-USD & $\begin{array}{c}\text { Year Signed/ } \\
\text { Implemented }\end{array}$ \\
\hline Kazakhstan & Zhongfu Investment Group into oilseed processing & \$1.2 billion & 2016 \\
\hline Kazakhstan & MangistauMunaiGas (50\%) & \$2.6 billion & 2009 \\
\hline Kazakhstan & Kazakh portion-Central Asia-China gas pipeline & \$6.7 billion & 2009 \\
\hline Kazakhstan & Ekibastuz GRES-2 Power Plant & \$400 billion & 2016 \\
\hline Kazakhstan & Kazakhstan-China Oil Pipeline & \$3 billion & 2006 \\
\hline Kyrgyzstan & Zhongda Oil Refinery & \$430 million & 2013 \\
\hline Kyrgyzstan & Kyrgyz portion-Turkmenistan-China gas pipeline & \$1.4 billion & 2016 \\
\hline Kyrgyzstan & North-South Highway & $\$ 400$ million & 2013 \\
\hline Kyrgyzstan & Thermal power plant & $\$ 386$ million & 2014 \\
\hline
\end{tabular}

Source: Strenberg, Ahearn, McConnell, 2017, p. 55.

Recently, the Chinese presence became more visible, particularly in Kazakhstan. According to some estimates, Chinese companies control up to $20 \%$ of Kazakh oil and gas production, and many local companies are heavily indebted to Beijing (Parkhomchik, 2016).

Table 5

Proposed One Belt, One Road (OBOR) investments

\begin{tabular}{||l|l|l||}
\hline \multicolumn{1}{|c|}{ Country } & \multicolumn{1}{c|}{ Potential OBOR Investments } & \multicolumn{1}{c|}{ Project } \\
\hline Kazakhstan & China-Central Asian pipeline & Natural gas \\
\hline Kazakhstan & Eurasian Land bridge & Railway corridor \\
\hline Kazakhstan & China-Central Asia-West Asia corridor & China to Iran rail link \\
\hline Kazakhstan & Khorgos-Aktau railway & Caspian to China link \\
\hline Kyrgyzstan & China-Kyrgyzstan-Uzbekistan railway & High-speed rail \\
\hline
\end{tabular}

Source: Strenberg, Ahearn, McConnell, 2017, p. 55.

Another challenge is the development of agricultural production in the Xinjiang province. Great Chinese investments in cotton production in Xinjiang are serious competition for Uzbek cotton producers. Beijing has invested USD 3 billion in tax benefits, 
rent and power subsidies to attract textile and apparel companies to Xinjiang, and aims to create one million textile jobs in the province by 2023 (Xinjiang, 2016).

The challenges for the Chinese investments, as seen within the framework of OBOR, are incompetence, corruption, and the unclear interests of the decision-makers in the administrations of individual states in Central Asia. According to Cooley, even Chinese officials expect that up to $30 \%$ of the funds allocated to the RDI in the Central Asia region will be wasted, a worse situation is to be found only in Pakistan (Lewis, 2016, p. 6).

Sebastien Peyrouse draws attention to at least two possibilities for drug trafficking. Firstly, drug smuggling has been facilitated by the ineffectiveness of border controls; the length of the external borders in Asia, and thus difficulties with their control, including their mountainous character (especially with regards to the border between Afghanistan and Tajikistan), as well as the lack of equipment of the border guards - despite international assistance - make the border porous. Secondly, the development of illegal drug trafficking in Central Asia has corruption as its foundation, and in some cases relies on the participation of security forces, which is particularly visible in Tajikistan (Peyrouse, 2017).

OBOR is a chance for development and breaking the isolation of the Central Asian region from other regions. However, the excessive economic expansion of China may lead to anti-Chinese sentiments, which have started to be noted on the occasion of various controversies related to Chinese investments.

\section{The European Union and OBOR - concluding remarks}

As Rumi Aoyama noted, One Belt, One Road is not limited to Eurasia but is a global strategy, and thus, the strengthening of relations in the five areas of policy, finance, trade, infrastructure, and people-to-people exchanges also applies to Africa and Latin America (Ayoma, 2016, p. 19). Most importantly, OBOR intends to include Europe as well. As in the case of Central Asia, OBOR brings many opportunities but also some threats. European partners are suspicious of Chinese state-owned enterprises operating under the OBOR framework, fearing unfair competition, as well as failure in maintaining standards related to the protection of intellectual property. As stressed by Theresa Fallon, some critics in the EU are paying attention to the fact that OBOR lacks transparency rules, and that opaque financing deals may threaten the competitiveness of European companies. The easy access of Chinese investors to strategic investments in Europe is not reciprocated by China with regard to European entrepreneurs. Another challenge lies in the fact that China has started to engage with Central and East European $(\mathrm{CEE})$ countries in a new type of platform within the CEE $16+1$ format. Eleven EU member states within the 16+1 format could form a pro-China lobby in Brussels, if they aligned their interests with China through this forum (Fallon, 2015, pp. 140-147). In the years 2007-2013, the European Union set priorities in its strategy towards Central Asia. Seven areas of cooperation have been identified, but the resources allocated are quite modest, about EUR 750 million in total. The EU has not been able to develop an effective model of cooperation due to the rather complicated EU procedures, as well as the corruption and bureaucratic inefficiencies of the Central Asian partners. 
In 2013, the Chinese Belt and Road initiative was announced, and it is a very comprehensive modernization, development and infrastructure proposal, compared to the EU's existing activities in the Central Asia region. It is both an opportunity and a challenge for the Central Asian states and the EU. In recent years, China's involvement in Central Asia has become a multifaceted network of pipelines and gas pipelines, commercial projects, trade exchange, investments in infrastructure as well as cooperation on security, within the framework of the Shanghai Cooperation Organization. The Chinese see the potential of Central Asia as an economic corridor for the Middle East and Europe. As the new strategy for Central Asia is being prepared, the European Union should take into account the importance of OBOR for the development of this region, and consider the possibilities and limitations for the European partners. The European Union should treat the development of OBOR connections as an opportunity to bring Central Asia closer. Currently, 95\% of trade between Europe and Asia is conducted using sea transport. The competitiveness of transport is usually assessed on the basis of three criteria: time, level of service and price. For the Central Asian inland economic corridor to be competitive with maritime trade, formalities and customs duties should be minimized, as well as procedures that slow down land transport relaxed.

OBOR presents a chance for the dynamic development of trade contacts and diversification in the supply of products from Europe and Asia, but with less favorable conditions, it may lead to Central Asia's dependence on China.

\section{Bibliography}

Aoyama R. (2016), “One Belt, One Road”: China's New Global Strategy, "Journal of Contemporary East Asia Studies," no. 5, vol. 2.

Bovingdon G. (2010), The Uyghurs: Strangers in Their Own Land, Columbia University Press, New York.

Cai P. (2017), Understanding China's Belt and Road Initiative, Lowy Institute for International Policy, March, https://www.lowyinstitute.org/sites/default/files/documents/Understanding\%20 China\%E2\%80\%99s\%20Belt\%20and\%20Road\%20Initiative_WEB_1.pdf, 22.07.2018.

Casarini N. (2016), When All Roads Lead to Beijing. Assessing China's New Silk Road and its Implications for Europe, "The International Spectator," no. 51, vol. 4.

Clarke M. (2017), The Belt and Road Initiative: China's New Grand Strategy?, "Asia Policy," Number 24, July 2017.

Contessi P. (2018), Foreign Policy Diversification and Intercontinental Transport Corridors: The Case of Kazakhstan's Railways Diplomacy, "Europe-Asia Studie,s" no. 70, vol. 5.

Fallon T. (2015), The New Silk Road: Xi Jinping's Grand Strategy for Eurasia, “American Foreign Policy Interests," no. 37.

Hansen V. (2012), The Silk Road: A New History, New York.

Laruelle M., Peyrouse S. (2015), Globalizing Central Asia: Geopolitics and the Challenges of Economic Development, London-New York.

Lewis D. G. (2016), Tackling Corruption in Uzbekistan: A White Paper, Open Society Foundation Policy Report, June.

Lim T. W., Chan H. H., Tseng K. H., Lim W. X. (2016), China's One Belt One Road Initiative, Imperial College Press, London, UK. 
Osiewicz P. (2016), Udziat państw Azji Centralnej w Szanghajskiej Organizacji Wspótpracy. Wnioski dla Unii Europejskiej, in: Unia Europejska wobec Azji Centralnej - uwarunkowania regionalne i międzynarodowe, eds. T. Wallas, R. Fiedler, Wydawnictwo FNCE, Poznań.

Parkhomchik L., China-Kazakhstan Relations in the Oil and Gas Sector, Eurasian Research Institute, http://eurasian-research.org/enlresearch/comments/energy/china-kazakhstan, 24.07.2018.

Peyrouse S. (2008), Chinese Economic Presence in Kazakhstan, http://chinaperspectives.revues. org/4053, 22.07.2018.

Peyrouse S. (2017), Diagnosing Central Asia's Drug Problem The Real Drivers Are Poverty and Corruption, Not Infrastructure, https://reconnectingasia.csis.org/analysis/entries/diagnosingcentral-asias-drug-problem/, 22.06.2018.

Ploberger C. (2017), One Belt, One Road - China's new grand strategy, "Journal of Chinese Economic and Business Studies," vol. 15, no. 3.

Popławski K., Kaczmarski M. (2018), Kolejowy Jedwabny Szlak. Połaczenia kolejowe UE-Chiny: uwarunkowania, aktorzy, interesy, "Prace OSW," no. 72, Warszawa, luty, https://www.osw. waw.pl/sites/default/files/prace_72_kolejowy_szlak_net.pdf, 20.07.2018.

Sternberg T., Ahearn A., McConnell F. (2017), Central Asian 'Characteristics'on China's New Silk Road: The Role of Landscape and the Politics of Infrastructure, "Land," no. 6 (3), vol. 55, http://www.mdpi.com/2073-445X/6/3/55/htm, 23.07.2018.

Szczudlik-Tatar J. (2015), Jedwabny Szlak: czym jest nowa priorytetowa chinska strategia, "Biuletyn PISM," no. 65, 2.07.2015, http://www.pism.pl/files/?id_plik=20063, 22.07.2018.

Tiezzi S. (2017), What did china accomplish at the belt and road forum?, "The Diplomat," 16 May, http://thediplomat.com/2017/05/what-did-china-accomplish-at-the-belt-and-road-forum/.

Qinan X. (2016), The New Silk Road in West Asia under "the Belt and Road" Initiative, "Journal of Middle Eastern and Islamic Studies," no. 10, vol. 1.

Xin L. W. (2016), China's One Belt One Road Initiative: A Literature Review, La Trobe University.

Xinjiang cotton at crossroads of new Silk Road, http://english.gov.cn/news/top_news/2016/02/15/ content_281475290185772.htm, 30.07.2018.

Verlare J., Putten F. P. (2015), One Belt, One Road'An Opportunity for the EU's Security Strategy, Clingendael Policy Brief, December.

Zicheng Y. (2010), Inside China's Grand Strategy: The Perspective from the People's Republic, University Press of Kentucky, Lexington.

\section{Summary}

China's Belt and Road Initiative is both an opportunity and challenge for Central Asian countries and the European Union. As an initiative announced in Astana, it may make Europe closer to Asia through railway connections. Its scope, proposed infrastructural investments and different connections and routes, additional initiatives and diplomacy suggest OBOR is in line with the global Chinese strategy.

Key words: Central Asia, Belt and Road, European Union, railway connections

\section{„Pas i Szlak” przez Azję Centralną - wnioski dla Unii Europejskiej}

\section{Streszczenie}

Inicjatywa Pasa i Szlaku stwarza możliwości jak i wyzwania dla regionu Azji Centralnej. Inwestycje infrastrukturalne wraz z rozwijającymi się połączeniami kolejowymi przybliżają 
ten region do Europy. Chińska inicjatywa wiąże się z koncepcją budowania strefy wpływów w regionie Azji Centralnej i stopniowego wypierania innych partnerów w tym państw Unii Europejskiej. W przygotowywanej nowej strategii UE wobec Azji Centralnej należy uwzględnić znaczenie Nowego Jedwabnego Szlaku z jego pozytywnymi jak i negatywnymi uwarunkowaniami.

Słowa kluczowe: Azja Centralna, Pas i Szlak, Unia Europejska, połączenia kolejowe 